\title{
REPRESENTACIÓN HUMANA Y GÉNERO EN PIEZAS DE METAL DEL NOROESTE ARGENTINO
}

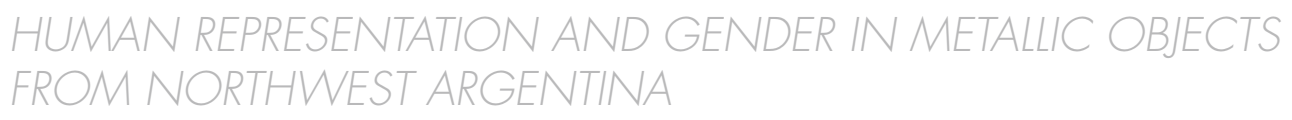

\section{GeralDINE GLUZMAN*}

En este trabajo analizamos desde la perspectiva de género un corpus de piezas metálicas en bronce del Noroeste Argentino (NOA) asignadas a los momentos prehispánicos tardíos. Las figuras femeninas presentes en diversos objetos han sido pocas veces estudiadas, limitándose a la mera descripción de las mismas, sin investigar sus relaciones con el soporte y su diálogo con otras representaciones. Tomando como punto de reflexión las representaciones femeninas en bienes de metal, indagamos las implicancias sociales de la presencia diferencial de imágenes sexuadas para momentos tardíos en el NOA y proponemos que existían mundos diferenciados de género pero interdependientes y complementarios.

Palabras clave: arqueología de género, metales, Noroeste Argentino, momentos prehispánicos tardíos

In this work we analyze a set of late pre-Hispanic bronze objects from the Northwest of Argentina (NOA) from a gender studies lens. The representation of female figures in diverse objects has rarely been studied; most of the time these objects are merely described without investigating their relationship to the medium and with other representations. Beginning with a reflection on the representation of women in metal objects, we explore the social implications of the differential presence of male and female images during the late pre-Hispanic period in NOA and propose that these reflect differentiated spheres of gender that are nonetheless interdependent and complementary.

Key words: gender archaeology, metals, Northwestern Argentina, late pre-Hispanic period

\section{INTRODUCCIÓN}

En esta contribución presentamos una reflexión desde el enfoque de género acerca de las características de las representaciones humanas en piezas de cobre o bronce del Noroeste Argentino. Si bien advertimos la ausencia de figuras humanas con rasgos sexuales masculinos en los bienes metálicos de los momentos prehispánicos tardíos (siglos x a Xv), existen evidencias de imágenes de mujeres con rasgos sexuales definidos, principalmente en peines elaborados en ese material. A partir de esta cuestión buscaremos indagar qué tipo de información brindan las piezas metálicas acerca de las relaciones de género en los valles calchaquíes para los momentos tardíos así como también sobre los contextos de uso de las mismas. Asimismo, nos proponemos mediante este caso alentar el estudio de las representaciones humanas desde la óptica de género incluso reconociendo sus dificultades, tales como que las imágenes no necesariamente nos informan sobre la realidad sino, la mayoría de las veces, sobre el intento de control de lo real. Como observa Gero (2001: 15; la traducción es nuestra),

[...] no podemos esperar (a) "ver" el género en el registro arqueológico más fácilmente que, por ejemplo, el clima o el origen étnico. Como el género, se trata de abstracciones complejas y compuestas que no se traducen simplemente y de una manera directa en un correlato material único. No sólo

* Geraldine Gluzman, Museo Etnográfico Juan B. Ambrosetti (FFyL, UBA), Moreno 350, (1091) Buenos Aires, Argentina, email: ggluzman@gmail.com 
el género no es una "cosa", ni siquiera es un conjunto estático de relaciones personales fijas. Las cuestiones de género son constantemente negociadas y reconstituidas, aprovechando la tradición, sorprendiendo con nuevas afirmaciones, a veces exageradas y a veces restando importancia; se realizan de manera rutinaria o estratégicamente.

Además, el empleo de fuentes etnohistóricas enriquecerá nuestra discusión sobre las relaciones de género para momentos tardíos debido a su proximidad temporal. Siguiendo a Brumfiel (2001) consideramos que la etnohistoria y la arqueología se complementan en este campo ya que ambas pueden proveer información donde una u otra es silenciosa.

Si bien se ha tendido a simplificar el estudio de género en ciencias sociales como un hecho de reivindicación de los derechos de la mujer, adentrarnos en la cuestión de género en arqueología no es únicamente una cuestión política, sino ante todo una manera de abordar el registro arqueológico desde los agentes sociales, es decir, de "humanizar el pasado" (Ruiz Martínez 2008: 144). La concepción de lo femenino y lo masculino es entendida como una construcción social particular, producto de un proceso histórico. El definir los roles masculinos y femeninos como constructos sociales nos obliga a analizar otras temáticas como la identidad y las jerarquías sociales, ya que los mismos atraviesan y están atravesados por estas últimas categorías.

Por otro lado, abogar por una arqueología de género involucra, asimismo, realizar una reflexión crítica acerca de los supuestos y las perspectivas que usamos para construir la evidencia arqueológica (Conkey 2003).

Frente a lo expuesto, analizar los modos de representación de las mujeres requiere inevitablemente analizar la presencia no sólo de los hombres sino de otros seres, es decir, buscar de modo totalizador el universo iconográfico en vez de caer en un nuevo sesgo de estudio.

\section{ESTADO DE LA CUESTIÓN}

En líneas generales, los estudios iconográficos en el NOA englobaron a las representaciones humanas bajo la categoría de "imágenes antropomorfas" sin buscar apreciar su género. En otras ocasiones, preponderaron las alusiones a las imágenes masculinas. En los últimos años, a pesar de los avances teóricos en arqueología acerca de las identidades sociales, los estudios de género no han prosperado. Paradójicamente, mientras que a partir de los nuevos desarrollos teóricos los seres humanos pasaron a ser divididos en segmentos sociales, los mismos permanecieron concentrados en la figura masculina (Cavicchioli 2006).
Curiosamente fueron los primeros arqueólogos, atraídos por las expresiones simbólicas de la cultura material del NOA, quienes mostraron un mayor interés en el análisis de las imágenes masculinas y femeninas sobre una diversidad de materiales. La presencia de representaciones de rasgos sexuales fue el principal medio de evaluación de género. Asimismo, los tipos de peinados fueron analizados para distinguir hombres y mujeres. Los diseños referidos a hachas y objetos ceremoniales (insignias de poder) se asociaron al dominio masculino y en particular a jefes étnicos, quedando los hombres comunes prácticamente invisibilizados.

Con el fin de precisar el género de las figuras, estos autores se enfocaron en el estudio de las representaciones antropomorfas en diversos soportes. Ambrosetti (1895) describe las pictografías de Carahuasi (provincia de Salta), donde la mayoría de los personajes portan escudos, instrumentos de guerra y penachos y plumas en sus cabezas. Ambrosetti señala a uno de éstos como el Inka, quien posee en una de sus manos una cabeza cercenada e interpreta la escena como una victoria militar de este soberano. La única mujer, que lleva en sus espaldas a un niño y un tocado de plumas, es para Ambrosetti una de sus esposas (1895: 327). Acerca de las petrografías de Las Cañas (provincia de Tucumán) describe una figura femenina "con los brazos levantados hacia arriba en actitud de oración" con representación de la vulva como "un triángulo con el vértice hacia arriba, y el cuerpo globuloso como si estuviera embarazada" (Ambrosetti 1897: 66) (fig. 1a). Por otro lado, Quiroga presenta dentro del conjunto iconográfico de la gruta Chiquimi (provincia de Catamarca) a "un ser femenino, por las mamas, abultamiento del vientre y la vulva profundamente calada en forma de mortero" (Quiroga 1992 [1931]: 257) a quien identifica con la Pachamama (fig. 1b). Además, analiza los símbolos asociados a cada género en otros de sus trabajos (Quiroga 1898, 1901). Outes y Bruch (1911: 53) retoman el estudio de las pictografías de Carahuasi, considerando que representan el episodio final de una acción guerrera, donde la tribu vencedora trae consigo las mujeres prisioneras y los animales cargados con el botín, apartándose de la idea de que se trata de la esposa del Inka. Este análisis conlleva la idea de sumisión femenina por el dominio masculino, asumida antes que estudiada.

Estos autores -interesados en cultos tales como los actos propiciatorios para producir lluvia para los cultivos y para la fecundidad de los rebaños- combinaron la lectura de las crónicas históricas, la recopilación de historias orales, el uso de analogías con otras culturas y la asociación de los animales representados con su hábitat para llevar adelante sus reflexiones. Este interés 

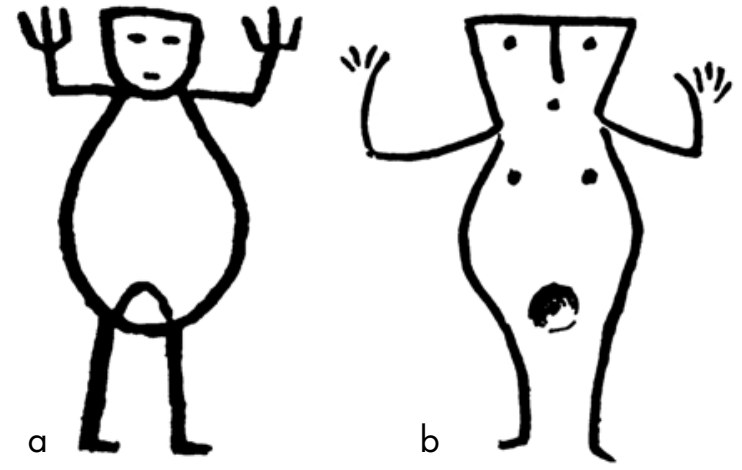

Figura 1. Representaciones femeninas a. Las Cañas; b. Chiquimi (tomado de Quiroga 1992 [1931]: 276 y 258; figuras 134 y 31). Figure 1. Female representations from a. Las Cañas; b. Chiquimi (from Quiroga 1992 [1931]: 276 \& 258; figures 134 \& 31).

generó una búsqueda integral de las representaciones femeninas y masculinas en el NOA, en seres humanos y en animales. Sin embargo, con el desarrollo de la arqueología moderna los abordajes de interpretación simbólica fueron dejados de lado en favor del estudio de cuestiones sociopolíticas y económicas desde un enfoque más riguroso. Desde entonces, los trabajos que indagan en cuestiones de género son escasos y se han caracterizado por tratar este tema en forma relativamente periférica.

A mediados de la década de 1970, A. González (2007 [1977]) inicia una vía de análisis estructural echando importantes raíces para el resurgimiento de los estudios de género, ya que retoma el tema de la presencia de un componente femenino-masculino en algunas imágenes antropomorfas duales. Weber (1981) propone, a partir de una analogía con la modalidad de vestimenta de tribus amazónicas (Shipibo-Conibo), la existencia de elementos iconográficos indicativos de género en las urnas santamarianas. Describe una distinción sexual en los dos tipos básicos de decoración del cuerpo de las urnas, aquellas con guarda central vertical y aquellas con brazos. Las primeras harían referencia a lo masculino, dada la verticalidad de los diseños, y las segundas, a lo femenino, considerando su horizontalidad y la disposición de los brazos que remarca los senos de la mujer. Al igual que Weber años atrás, Velandia (2005) también emplea analogías con diseños faciales de las mujeres Caduveo en el estudio de las urnas funerarias santamarianas y sostiene que son representaciones de mujeres sentadas, ataviadas y pintadas con las marcas de su rango o de sus linajes, para asistir al funeral de sus niños muertos. Las imágenes de las urnas están reflejando las mantas o los unkus, la pintura facial, los tatuajes o las máscaras.
Recientemente Scattolin (2006) observó la poca atención que recibió la figura de una "mujer que carga un vaso" en la alfarería del NOA, la cual llamativamente fue descrita por Uhle en 1912. Scattolin (2006: 43) explica que

[...] más allá del interés por el rol de la mujer en el pasado, mi propósito apunta a contribuir a una discusión de las relaciones de desigualdad y dominación que anidaban en estas sociedades aldeanas, ya que las distinciones sexuales, organizadas según la división en géneros relacionales, podrían constituir uno de los principios en los cuales se fundaron los llamados "procesos de jerarquización" de dichas sociedades.

Scattolin inaugura de este modo una arqueología explícitamente de género para el NOA a partir del análisis de la representación de la mujer en ciertas sociedades aldeanas del primer milenio DC. Analiza cómo la iconografía ha sido usada para sostener argumentos sobre desigualdad sociopolítica en estas comunidades, al tiempo que reflexiona acerca de cómo la misma pudo contribuir a instituir los principios que fundan las diferencias sexuadas.

\section{REPRESENTACIONES ANTROPOMORFAS}

Las imágenes antropomorfas en piezas de metal asignadas a los momentos tardíos se caracterizan por la rigidez y la extrema síntesis de los rasgos corporales, elaborados a partir de trazos en relieve. Se inscriben en un patrón estandarizado de representación que cruza diversos soportes y se denomina comúnmente estilo santamariano. ${ }^{1}$

En las piezas metálicas el modo más común de manifestación de los seres antropomorfos es mediante el diseño en relieve del rostro humano, que aparece aislado, de a pares o de a cuatro y presenta escasos detalles de sus rasgos faciales (fig. 2). Son diseños elaborados a partir de trazos continuos en un molde donde luego se vertía el metal. Las cabezas tienden a ser triangulares, con mentones en punta u ovalados, con la boca abierta y los ojos circulares. A veces nariz, boca y ojos se componen de una sola línea delgada, aunque pueden poseer representación de dientes y lengua. Una característica particular de las representaciones sobre metal es la presencia de líneas verticales debajo del mentón de algunos de los rostros. Estos han sido interpretados como cabezas cercenadas y, además, las líneas representarían "los elementos destinados a sostener, llevar y manipular la cabeza cercenada" (González, A. 1992: 251).

Otro modo de representación humana son las figuras completas destacándose los "guerreros", que visten petos 


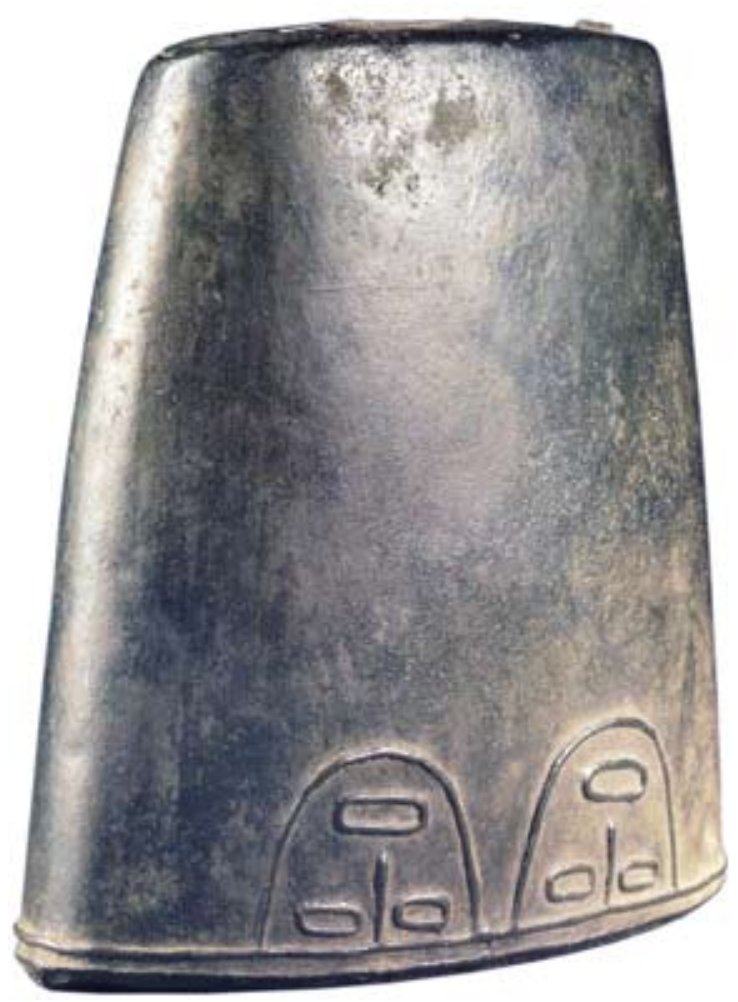

Figura 2. Campana de sección oval (tomado de Goretti 2006: 113, alto: $230 \mathrm{~mm}$ )

Figure 2. Oval-shaped bell (from Goretti 2006: 113, height: $230 \mathrm{~mm}$ ).

a modo de trajes, y las figuras "con túnicas". En los discos metálicos los personajes enteros se registran generalmente de a pares y visten escudos o túnicas decoradas con guardas, cruces, círculos, aves o serpientes (fig. 3). Por su actitud y/o elementos asociados, la mayoría de estas imágenes denota situaciones de violencia. En las urnas santamarianas de la tradición Yocavil, especialmente para las fases IV y V destaca la asociación entre motivos felínicos y estas figuras (Nastri 2005), lo que nos invita a reflexionar sobre las razones de su aparición en momentos de aumento de conflictos en la zona, ya que su cronología es muy tardía. ${ }^{2}$ Es común que estos personajes lleven armas en sus extremidades o posean cabezas cercenadas anexas. Una característica de los personajes completos y de los rostros aislados es la presencia de diversos tipos de tocados y de collares. Los tocados cefálicos pueden ser en forma de tumi invertido, penachos de plumas o voluminosos peinados (González, L. 2007) y sus grados de elaboración posiblemente nos estén informando acerca de jerarquías sociales. Las imágenes descritas carecen de rasgos sexuales definidos, pero su asociación al felino y a actividades guerreras conduce a pensar que representan figuras masculinas.

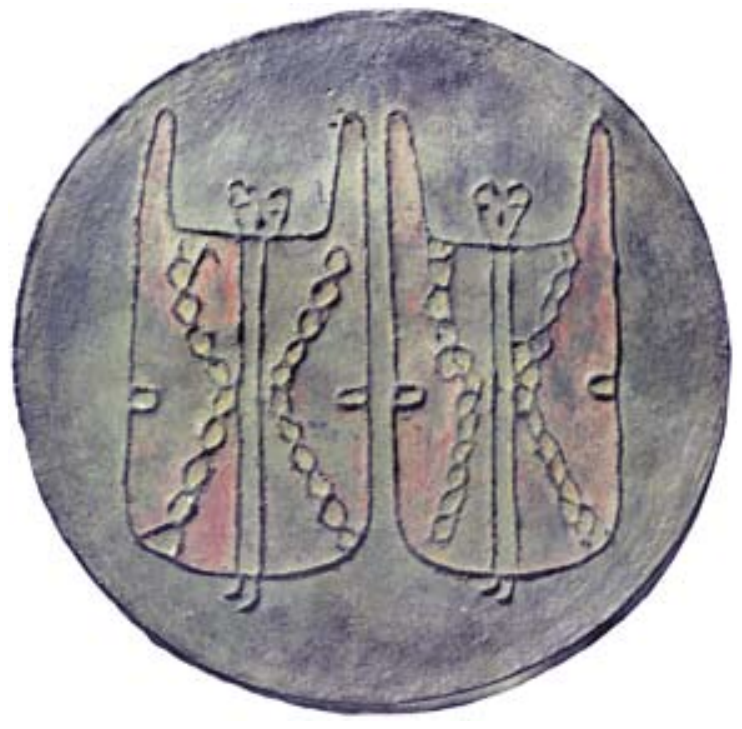

Figura 3. Disco con guerreros (tomado de Goretti 2006: 117, diámetro: $225 \mathrm{~mm}$ ).

Figure 3. Disc with warriors (from Goretti 2006: 117, diameter: $225 \mathrm{~mm}$ ).

Por otro lado conocemos seis piezas elaboradas en cobre o bronce, tres peines, dos placas y un topu o alfiler con cabeza discoidal, con representaciones femeninas. Si bien no sabemos cuál es su composición elemental, estimamos, en función a la producción metalúrgica de la época, que son de cobre o de una aleación de cobre con bajo contenido de estaño. Sólo uno de los tres peines ha sido publicado en trabajos sobre arte precolombino (González, A. 1977: 298) o en catálogos de piezas prehispánicas (Goretti 2006: 172). Tampoco han sido incorporados en trabajos de síntesis tipológicas, a pesar de su temprano ingreso a los museos. Recientemente uno de ellos fue publicado por L. González (2008) interesado en la rareza de la pieza. En cambio, una de las placas -aquella que posee claramente una imagen femenina- ha sido reproducida por Quiroga (1901: 193), Ambrosetti (1904: 270, figura 74) y A. González (1992: 113, lámina 41). Si bien ya había sido publicada en otras oportunidades, le correspondió a A. González (1992) la interpretación de que la otra placa rectangular poseía dos figuras femeninas. El topu fue publicado por Ambrosetti (1904). ${ }^{3}$ Sobre estas dos placas volveremos luego.

Importante es resaltar que estas piezas, como la mayoría de las piezas metálicas del área, carecen de información contextual. Estas han ingresado a los museos mediante compra durante el período de formación disciplinaria (fines del siglo XIX y primera década de principios del xx) y se estima que procederían de entierros (González, A. 1983, 1992). 


\section{Peines y representaciones femeninas en el Período Tardío}

Los peines de metal se caracterizan por sus pequeñas dimensiones con un alto promedio de $100 \mathrm{~mm}$. De escaso espesor, se trata de piezas cuyos mangos han sido modelados en un molde refractario en forma antropomorfa. Los dientes del peine, cuyo número varía entre 11 y 24, se ubican en la base de las representaciones, que carecen de piernas ya que luego de la pelvis están los dientes del peine.

Los diseños en relieve de estos peines son típicos del Período Tardío. A diferencia de hachas, campanas y placas, asociadas al ceremonial religioso de la región, que incluía prácticas sangrientas tales como el cercenamiento de cabezas, estas piezas habrían sido de uso personal, aunque se trataría de objetos suntuarios. Esta apreciación se fundamenta principalmente en su materialidad. Constituyen piezas elaboradas en metal, cuyo proceso de producción involucraba un complejo sistema organizacional en lo que respecta a la obtención de recursos (entre otros, minerales y combustibles) y a la necesidad de varios operarios capacitados. Asimismo sus propiedades en cuanto al color, brillo, plasticidad, durabilidad, sonido y capacidad de reflejar, fueron muy valoradas en las sociedades del NOA en tiempos prehispánicos.
Si bien no conocemos los contextos de hallazgo, consideramos que estos peines debían pertenecer a mujeres. Existen datos etnográficos (Isbell 1997) e históricos que fortalecen esta interpretación (Guamán Poma 1992 [1615]). Según estos, los peines formarían parte de los elementos asociados al aseo personal y el cabello femenino denotaría belleza.

Peine Museo de Belén (fig. 4a). Procede del valle de Hualfín (provincia de Catamarca) (González, A. 1977: 298). Es de forma cuadrangular y mide $115 \mathrm{~mm}$ de largo y $70 \mathrm{~mm}$ de ancho. Posee la imagen de una mujer desnuda, con signos de vulva, clítoris y senos. Su rostro es triangular. Sus ojos y su boca están abiertos y una línea delgada hace de nariz. Brazos y manos están integrados al cuerpo, diseñados con trazos delgados. Muestra un collar de dos vueltas.

Peine Museo de La Plata (fig. 4b). Su largo es aproximadamente de $95 \mathrm{~mm}$. Carece de signos que aludan a pechos pero están representados los genitales femeninos, con el clítoris marcado. Su cuerpo es ovalado y sus brazos fueron modelados en vez de haber sido ejecutados por líneas en relieve. El rostro es triangular con el mentón ovalado.

Peine Museo de La Plata (fig. 4c). Es el único que examinamos y fotografiamos de manera directa. ${ }^{4}$ Mide $96 \mathrm{~mm}$ de alto, $50 \mathrm{~mm}$ de ancho en la base de los dientes y su espesor es de $4 \mathrm{~mm}$. Procede de la provincia
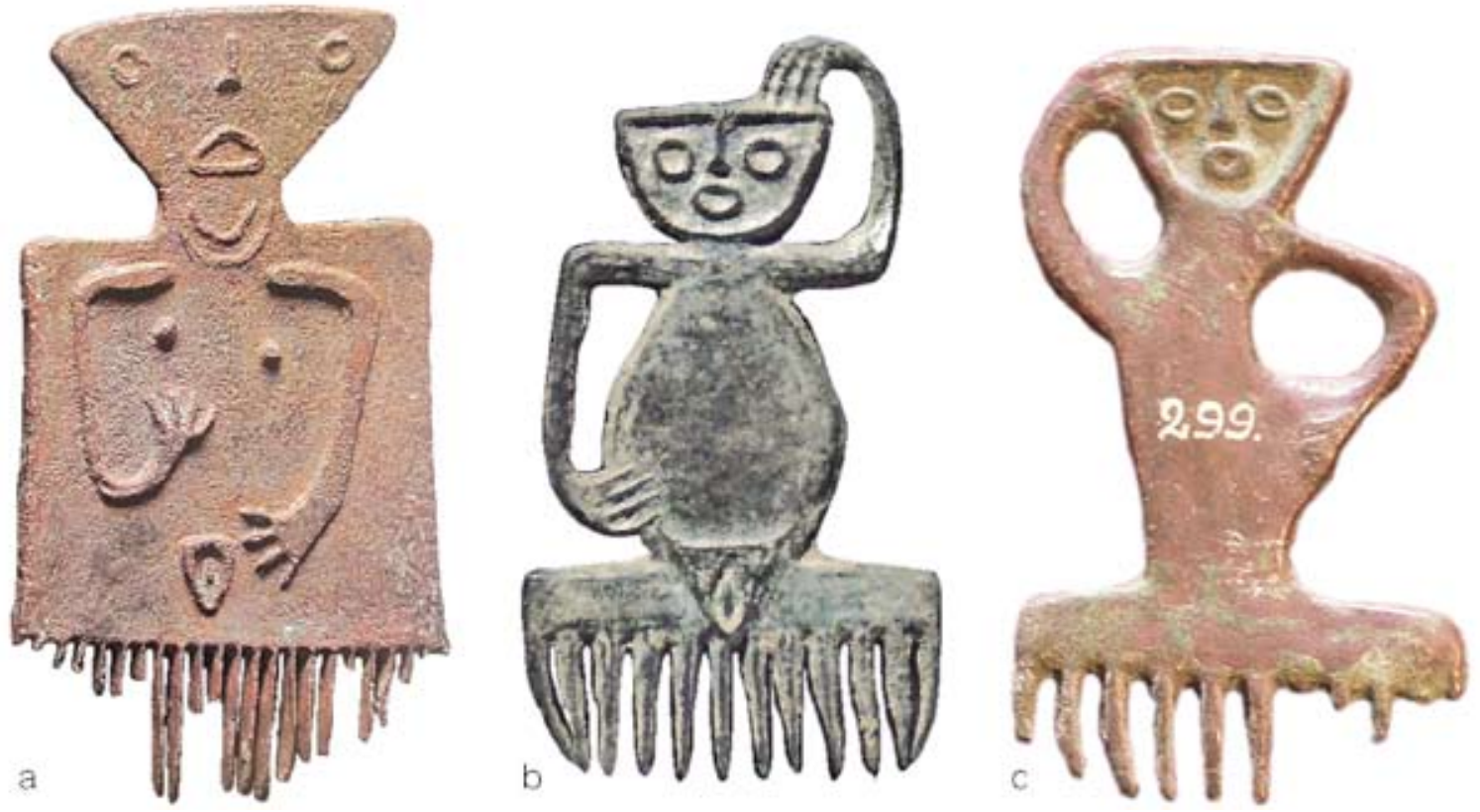

Figura 4. Peines metálicos: a. (tomado de Goretti 2006: 172, alto: $115 \mathrm{~mm}$ ); b. (tomado de González, L. 2008: 64, figura 4, alto: 95 mm); c. alto: $96 \mathrm{~mm}$.

Figure 4. Metal combs: a. (from Goretti 2006: 172, height: $115 \mathrm{~mm}$ ); b. (from González, L. 2008: 64, figure 4, height: 95 mm); c. height: $96 \mathrm{~mm}$. 
de La Rioja. Carece de atributos indicativos de sexo. Consideramos que se está representando una túnica, lo cual aleja esta imagen de la desnudez de las restantes. El cuerpo es ligeramente romboidal y los brazos fueron modelados. La cara es de forma triangular y su mentón ovalado.

Se conocen peines de madera con dientes de espinas de cardón en diversos sitios del NOA (por ejemplo Lehmann-Nitsche 1904, Cigliano 1958). Ambrosetti (1907) reporta el hallazgo de peines de madera en varios sepulcros de La Paya (provincia de Salta). Según este autor "estos objetos en vez de ser utilizados para arreglarse el cabello, parece que hubieran sido empleados para cardar la lana de las llamas ó vicuñas, tejidas" (Ambrosetti 1907: 239). Más allá de su funcionalidad, tres de los ejemplares tienen talladas en su parte superior una figura humana. En Kipón, Debenedetti (1908) reporta un peine de madera que posee en el mango una imagen antropomorfa y que según este autor representa una mujer.

Las tres mujeres diseñadas en los peines metálicos se presentan aisladas: el soporte, en este caso el peine, no es ajeno a la connotación de lo femenino ya que el mismo sirve como límite de la figura. Objeto y mujer se confunden y se genera un objeto-efigie. ${ }^{5}$ Esto las aleja de las imágenes presentes en hachas, discos y campanas, en donde las figuras masculinas son parte de la representación total del diseño no sólo porque muchas veces se registran con otros hombres, motivos zoomorfos o abstractos, sino también porque el soporte es independiente a su misma configuración. Estas usan la técnica de bajorrelieve y ocupan un panel o porción de la pieza pero no conforman objetos-efigie.

Si bien el mismo soporte nos indica que los peines se relacionan con la esfera privada, consideramos que son de uso personal por esta íntima relación entre la forma y la figura. Por el contrario, los otros bienes metálicos mencionados se vinculan a rituales o actividades guerreras. De este modo ingresamos a dos universos diversos aunque interconectados, el de la esfera privada y la pública (ver más adelante).

En las piezas metálicas, los rostros se encuentran principalmente en hachas, placas, campanas y ocasionalmente en cuchillos rectangulares. Al comparar los rostros femeninos y los masculinos notamos que las características de las representaciones cruzan los géneros. Realizados en diferentes soportes (talla en madera, arte rupestre, metalurgia, cerámica), su importancia nos lleva a reflexionar acerca de una concepción donde la cabeza es privilegiada sobre el resto del cuerpo. La cabeza humana constituye el nudo central de poder y autoridad. Subyace el uso de la metonimia como recurso expresivo y comunicativo y cuyo desarrollo habría sido de larga data en el área si tenemos en cuenta las máscaras líticas del Período Temprano. Es entonces el vínculo entre la imagen y el soporte, así como el tipo de bien sobre el cual la imagen se representa, y los elementos asociados (líneas submentonianas, tocados o peinados) lo que identifica los rostros aislados en las piezas de metal como masculinos. Los rasgos faciales no son significativos de género (y posiblemente tampoco de identidad). Tanto las caras como los guerreros aparecen en piezas metálicas de uso no cotidiano y trasmiten información sobre la actividad guerrera y la ideología funcional al grupo dominante (González, L. 2007).

El análisis de las figurillas femeninas presentes en otros soportes y pertenecientes a los momentos tardíos nos revela que la mayoría carecen de manifestaciones de tocados, más representados en las figuras masculinas (Tabla 1). ${ }^{6}$ En cambio, muchas mujeres aparecen representadas con peinados que consisten en el pelo dividido al medio y repartido en dos trenzados (González, A. 1977: 322; Quiroga 1992 [1929]: 456) o sin trenzar (Ambrosetti 1907: 187) (Tabla 1). Consideramos que las representaciones en peines no poseían tocados precisamente por el tipo de soporte. De este modo, el objeto funciona como espejo en sentido metafórico; estas imágenes reflejan la actividad en el momento cotidiano de uso. Como sus propietarias, se están peinando (como en el caso de los peines b y c), o acicalando (como en el peine a).

Los tocados no eran de uso exclusivamente masculino. Arriaza y otros (1986) examinan diferencias de géneros en momias procedentes de cementerios de Arica, norte de Chile. Si bien no existen en calidad diferencias en las camisas de las momias (aunque los hombres poseen ropa más decorada), los peinados separan a hombres y mujeres de modo dramático. Los peinados de los hombres tienden a presentar una mayor variedad de estilos complejos mientras que las mujeres principalmente tienen trenzado lateral. Frente a esto, concluyen que los estilos en el peinado, más que el vestido, indican que los hombres poseían una mayor variedad de roles sociales. De este modo, el peinado o los tocados como elemento extracorporal pueden ser significativos de género, así como de identidad y de roles sociales. Proponemos como hipótesis que las expresiones de mujeres que poseen trenzas (o carecen de peinado) en vez de tocados representan mujeres en contextos cotidianos y no en contextos ceremoniales.

Las mujeres, al igual que los hombres, pueden estar representadas sin rasgos sexuales explícitos (Tabla 1). Muchas veces cuando las mujeres no los poseen se debe a que se trata de representaciones femeninas con túnicas poco decoradas o sin diseños decorativos (Tabla 1). 


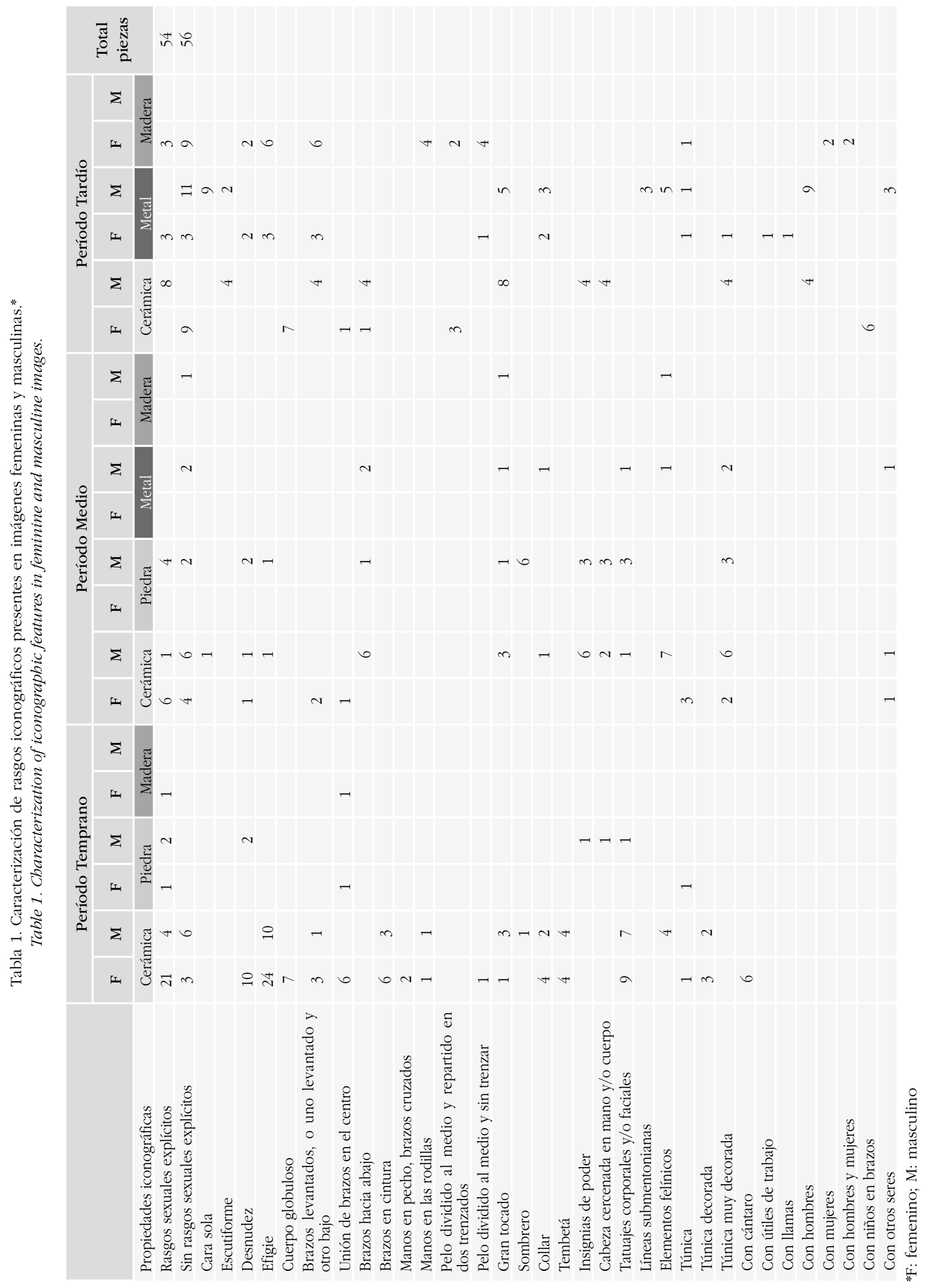


Cruzando aquellas imágenes con estos rasgos con otras que no los tienen, vemos que pueden presentarse con las extremidades semiflexionadas (tanto brazos como piernas), con cuerpo abultado (en este último caso con una cabeza pequeña en relación con el cuerpo) (Tabla 1). Existe un predominio de mujeres representadas con ambos brazos levantados (o uno levantado y otro bajo), o unidos en el centro del cuerpo, mientras que las imágenes masculinas prevalecen los brazos hacia abajo (muchas veces con insignias de poder que le cuelgan de las extremidades).

Asimismo, observamos que la figura femenina es más abundante para el Período Temprano (600 AC-650 DC) y Medio (650-850) (periodificación sensu González, A. 1964). Si bien esto pueda deberse a cuestiones de muestreo diferencial (Tabla 1), resaltamos que se conocen representaciones femeninas del Período Temprano en arte rupestre con implementos utilitarios en las manos, como en la quebrada de Matansillas (provincia de Salta) (Muscio 2006: 23) y elaboradas en cerámica transportando cántaros (entre otros, Goretti 2006: 174, Scattolin 2006: 49). Por otro lado se reconocen representaciones Condorhuasi de mujeres con tatuajes o pinturas corporales, así como tembetá (entre otros, González, A. 1977: 110-116; Goretti 2006: 143, 148, 158, 166) (fig. 5). Para Candelaria se observan siluetas femeninas con cuerpos globulosos, senos cónicos y cuerpos rechonchos que destacan pliegues adiposos (González, A. 1977: 141; Alberti 2007; Alberti \& Marshall 2009). Como hemos dicho, muchas veces los brazos se orientan uno, hacia
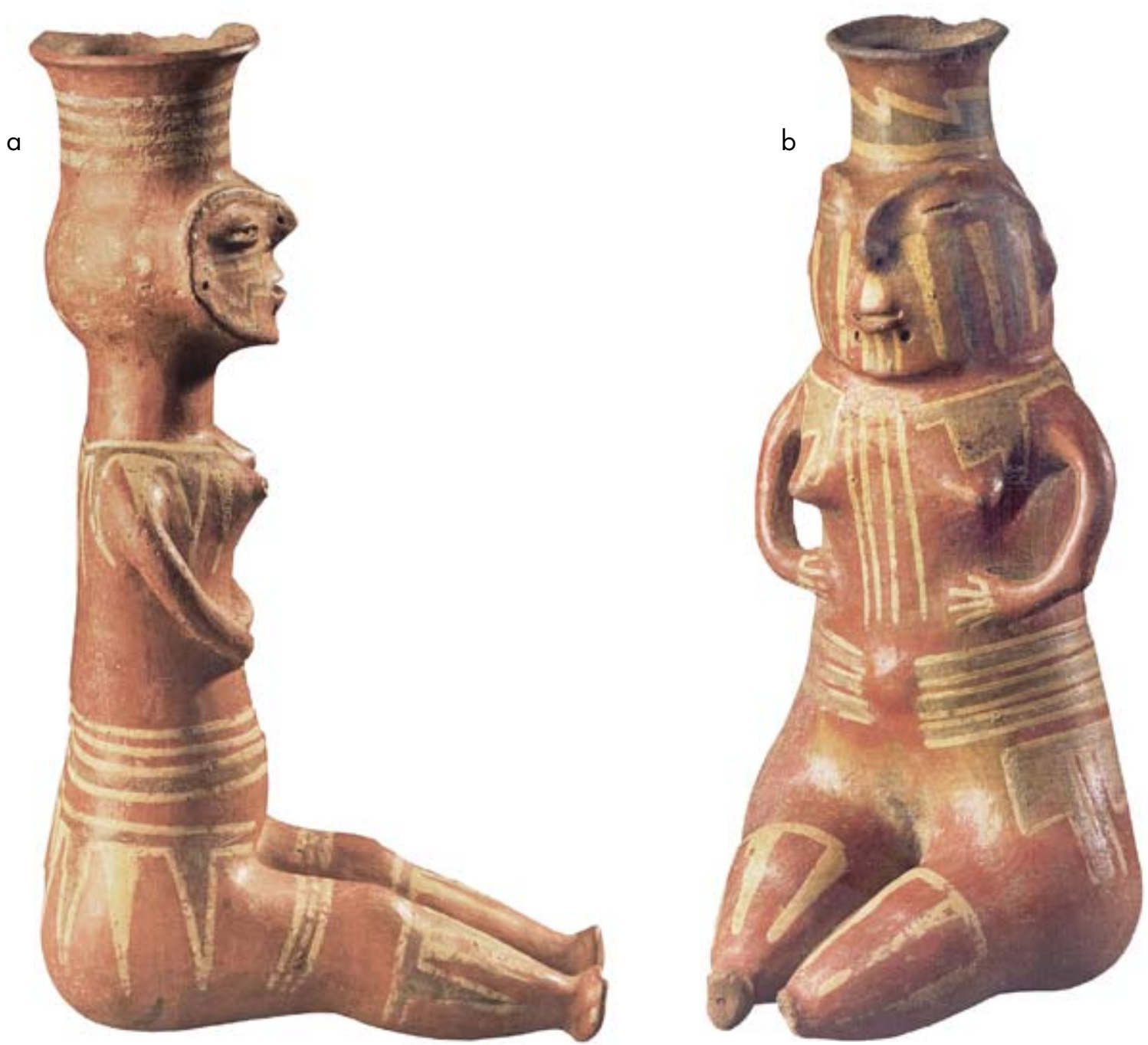

Figura 5. Representaciones femeninas Condorhuasi: a. (tomado de Goretti 2006: 148, alto: $311 \mathrm{~mm}$ ); b. (tomado de Goretti 2006: 161, alto: $150 \mathrm{~mm}$ )

Figure 5. Condorbuasi female figurines: a. (from Goretti 2006: 148, height: $311 \mathrm{~mm}$ ); b. (from Goretti 2006: 161, height: $150 \mathrm{~mm}$ ). 
la cabeza, mentón o boca, y el otro hacia su órgano genital (Tabla 1). Ambrosetti (1907: 492) apoda a esta figura como la "Venus Calchaquí". Lo que prima en estas representaciones es su desnudez y frente a la vestimenta masculina que los cubre, haciendo incluso el escudo de límite de su cuerpo, y los protege de los enemigos, vemos a estas mujeres en señal de "desprotección" resaltándose el contorno de la silueta femenina. Vale destacar que, a diferencia de las representaciones masculinas, las femeninas no están pintadas en cerámica como diseños internos del universo plástico sino que toman todo el contorno de la pieza (objeto-efigie) o aparecen como apéndices modelados. Sin embargo Ambrosetti (1907) consigna el género de imágenes pintadas en un aríbalo de La Paya y destaca que en estas figuras las mujeres poseen la cabeza sin tocados "pero abultada, negra y terminada en curva con el agregado muy sugestivo de una línea vertical a cada lado de la cabeza, que, a mi entender, es la representación sintética de ese curioso peinado de moño" (Ambrosetti 1907: 285) (fig. 6), moño que, a través del uso de la analogía directa, anteriormente había asociado al uso femenino dada la similitud de este peinado con los que empleaban en ese entonces mujeres Pueblo (Ambrosetti 1899). Independientemente si se trata de un moño, o representa otro elemento, a destacar es la observación de este rasgo y su posible asociación a las imágenes de mujeres.

De este modo, podemos resumir las imágenes femeninas del Período Tardío del siguiente modo: mujeres aisladas o en pequeños grupos de predominio masculino, con niños en sus brazos o espalda, bajo su cuidado; a

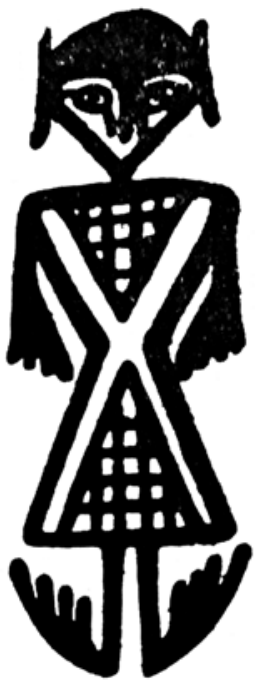

b

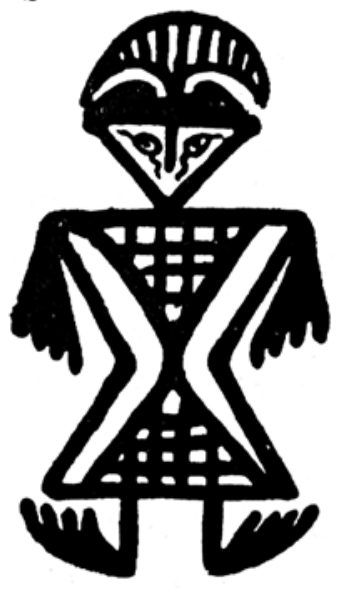

Figura 6. a. Representación femenina (alto: $195 \mathrm{~mm}$ ); b. masculina (alto: $170 \mathrm{~mm}$ ) (tomado de Ambrosetti 1907: 285, figura 124).

Figure 6. a. Female representation (height: $195 \mathrm{~mm}$ ); b. Male representation (height: $170 \mathrm{~mm}$ ) (from Ambrosetti 1907: 285, figure 124). vestidas con largas túnicas, desnudas haciendo explícitos sus rasgos sexuales secundarios; con trenzas o pelo sin trenzar hacia los costados de la cabeza, escasamente representadas con tocados (Tabla 1). Aparecen en el arte parietal y en diversos tipos cerámicos de reducidas dimensiones, en objetos de madera (Ambrosetti 1907) y en escasa medida en metal, con relación a la cantidad de representaciones masculinas en ese soporte. De este modo, la metalurgia fue una tecnología de poder masculina, en la que las representaciones de mujeres habrían tenido poca visibilidad siendo empleados los objetos en espacios ceremoniales donde se ponían en juego símbolos asociados a la autoridad vigente. En cambio, la imagen de la mujer habría sido empleada en ámbitos domésticos, como se destaca en algunos torteros de madera de La Paya (fig. 7), en peines, o en pucos decorados. Desde una perspectiva que tenga en cuenta la noción de complementariedad andina, el hecho de que las mujeres estén pobremente representadas en los objetos de metal nos indicaría que se trata de un ámbito de acción ajeno a ellas.

\section{FUENTES HISTÓRICAS}

Si bien no existe abundante información etnohistórica del área, es posible tomar algunos datos que indirectamente hacen referencia a las relaciones de género. Es necesario ser cautelosos ya que las opiniones de los españoles de los siglos XVI y XVII están sesgadas por sus propias concepciones ideológicas contemporáneas de género.

Las diversas fuentes sugieren una marcada división sexual del trabajo: mientras los hombres cazaban y fabricaban arcos y flechas, las mujeres se encargaban del cuidado de los cultivos, hilaban, tejían, molían y se
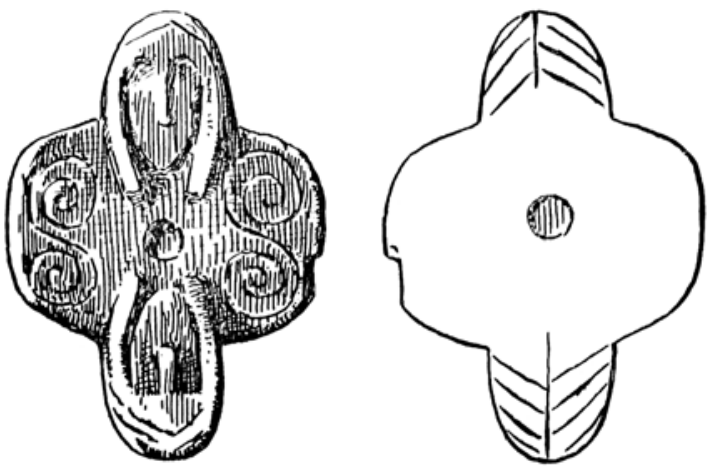

Figura 7. Tortero de madera (tomado de Ambrosetti 1907: 187, figura 91, alto: $55 \mathrm{~mm}$ ).

Figure 7. Sketch of a wooden spindle whorl (from Ambrosetti 1907: 187, figure 91, beight: $55 \mathrm{~mm}$ ) 
ocupaban de otras tareas domésticas (Amigó 2000). De interés es observar en una Carta Anua de 1618-1619 se describe cómo los grupos locales recibían a los jesuitas (en Amigó 2000: 37):

Comenzaron a venir a vernos los curacas [...] venían como en procesión los indios delante con los mejores aderezos que tenían y su arco y flechas detrás, las indias cargadas con Hancá (que es maíz tostado) otras con harina de maíz, otras con porotos [...] y otras con gallinas y huevos, y otras con tinajuelas de chicha diferentes en la cabeza.

Esta cita nos muestra las jerarquías que se explicitaban frente al español, ya que a la cabeza de la procesión se ubicaban los curacas, luego los guerreros y finalmente las mujeres que llevaban la comida. El consumo de chicha y el rol de la mujer en su transporte queda reflejado en la siguiente Carta Anua de 1653-54 (en Amigó 2001: 195) donde también vemos la importancia de la cosecha de la algarroba en el Valle Calchaquí al congregar a

[...] todo el valle con más solicitud que a la vendimia en Europa, porque de ella sustentan todo el año desatinadas las borracheras convertida en chicha, que beben a todas ocasiones y con público concurso, siendo estimado este como principal empleo, y todas las demás ocupaciones como accesorias [...] salen al lugar de su labor donde les siguen las mujeres con los cántaros de chicha [...] Beben largo y se calientan, al tiempo que los hechiceros entre muchachas livianas que se afeitan y adornan a su usanza les dan música para los convidados apacibles, ofreciendo juntamente inmundos sacrificios al demonio, cuya defensa imploran el resguardo de sus sementeras.

Asimismo, si bien debemos relativizar esta observación, las Cartas Anuas (citado en Amigó 2000: 93) sugieren el dominio masculino frente a las actividades femeninas

[...] sin permitirlas [a las mujeres] jamás ociosas, en tanto extremo, que las obligan más al trabajo que a los varones mismos [...] las ejercitan ya hilando, ya tejiendo con los hilados sus mantos y sus vestidos, ya moliendo [...], y cuando faltan materiales a las ocupaciones dichas, las aplican a desyerbar los sembrados, encaminarles el agua, y defender de sus frutos [...], y esto el tiempo que les sobra de los ministerios domésticos, como son acarrear el agua, leña, guisar, aderezar las comidas, manjares para la mesa, la chicha.

Las crónicas también muestran que aquellos curacas con mayor capacidad de movilizar recursos poseían más mujeres. De hecho, el falso Inka Bohórquez habría accedido a más de una esposa al convertirse en el representante del poder absoluto en el valle, siendo la mayor parte de sus mujeres hijas de curacas (Amigó 2000). De este modo, las mujeres, como los obsequios, eran parte de un sistema de dádivas esencial dentro de la redistribución económica (Bunster 2001).
También existen datos que remiten a otras actividades (Amigó 2000: 89):

Cayó veloz un rayo no muy lejos de una india casada con un principal cacique [...] De aquí formaron agüero los hechiceros diciendo que era aquel presagio del cielo en que sus dioses mostraban querer a la venturosa india para sacerdotisa.

Esta cita nos informa sobre la importancia del rayo en la religiosidad calchaquí. Que fuera mujer del curaca principal nos indica su estatus más elevado en su comunidad. Asimismo es posible interpretar a las "muchachas livianas" anteriormente mencionadas como hechiceras, descritas peyorativamente de ese modo dentro de la concepción religiosa de los sacerdotes.

Asimismo, las crónicas hacen referencia a la importancia simbólica de las cabelleras y tocados entre los hombres. El Padre Del Techo (1673) señala que "los principales ciñen la frente con una diadema de plata ú oro" y que llevaban "largas cabelleras y corona de plumas". Es interesante mencionar la imagen de la placa metálica circular conocida como "disco Vázquez" (fig. 8). Allí hallamos un gran rostro con un complejo tocado en el centro de la placa. A. González (1992: 72) observa que "la cuidadosa elaboración del peinado sugiere que el sacrificado debió ser [...] un sujeto del sexo masculino y además un personaje de importancia dentro de la jerarquía tribal, quizás el jefe de un grupo enemigo vencido". Sin embargo, como hemos visto, el pelo era considerado una sustancia privilegiada y por lo tanto sometida a una muy especial manipulación

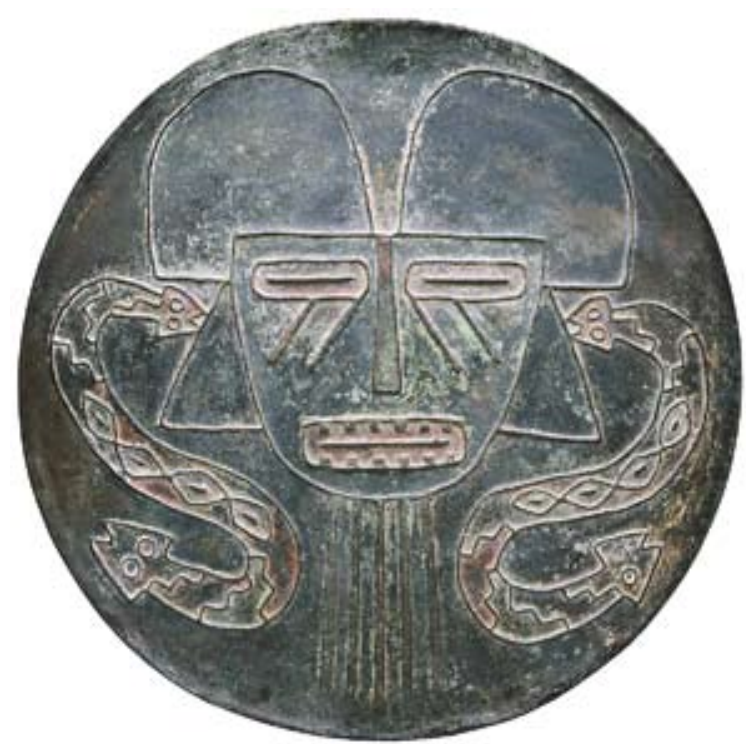

Figura 8. Placa circular conocida como disco Vázquez (tomado de González, A. 1992, lámina 25, diámetro: 392 mm).

Figure 8. Circularplate known as the Vázquez disc (from González, A. 1992, plate 25, diameter: $392 \mathrm{~mm}$ ). 
social (Gallardo 1994), lo cual no sólo se circunscribía a los curacas.

Alejándonos del área del NOA, diversos grabados de Guamán Poma exponen una división de roles según género en varios ámbitos de la vida. El correspondiente a "junio, descanso de la cosecha" (fig. 9a) muestra cómo el inka "ueue con el sol en la fiesta del sol". De pie, dirigiendo su mirada al Sol, el Inka tiene en su mano un vaso con chicha. A sus pies una mujer sentada sirve la bebida contenida en un aríbalo en el vaso. Esta cubre sus hombros con una lliclla, prendido con un topu, y su cabeza con un pañuelo (Guamán Poma 1988 [1615]: 221). Para la fiesta del mes de septiembre, mes del festejo de la Coya Raymi, por la gran fiesta de la Luna, nos muestra tres nobles guerreros con hondas encendidas con fuego y llevando escudos rectangulares mientras que la Luna los sigue con la mirada (fig. 9b). Guamán Poma (1988 [1615]: 227) explica que

[...] y en este mes mandó los Yngas echar las enfermedades de los pueblos y las pistelencias de todo el rreyno. Los hombres, armados como ci fuera a la guerra a pelear, tiran con hondas de fuego, deziendo " ¡Salí, enfermedades y pistelencias de entre la yente y deste pueblo!".

En esta fiesta, las mujeres "convidan" a los hombres. En este dibujo la mujer no está presente, sólo la Luna, "coya y señora del sol".

González Vargas, Rosati y Sánchez (2001) realizan un minucioso análisis de las láminas de Guamán Poma a partir del "estudio de la lateralidad". Siguiendo un patrón de observación basado en los modelos de pensamiento indígena, consideran que las representaciones se organizan bajo un riguroso orden jerárquico y dual basado en pares de términos opuestos y complementarios (arriba-abajo, derecha-izquierda, masculino-femenino, anciano-joven, cielo-tierra). Entendiendo que los dibujos de la crónica están en diálogo real con el lector, y que la izquierda del lector corresponde a la derecha de la lámina y viceversa (González Vargas et al. 2001), observamos una correspondencia entre, por un lado, arriba, derecha, masculino, anciano y cielo, y por otro, abajo, izquierda, femenino, joven y tierra. Para la primera de las láminas antes mencionadas destacamos la relación arriba-abajo según la jerarquización andina, expresada en la presencia del Sol en la parte superior (mundo divino) y en la parte inferior, del lado derecho el Inka. Un eje vertical virtual lo separa de la mujer que se ubica en la izquierda (González Vargas et al. 2003: 176-177). En la segunda lámina vemos que en el extremo superior derecho no está el Sol sino la Luna, debido a la celebración de la fiesta de este cuerpo celeste. Según estos autores, el hecho de que los guerreros se dirijan hacia la izquierda puede estar significando que están "en función de una actividad presidida por las mujeres" (González Vargas et al. 2003: 181-183). De todas formas, al menos desde este grabado, percibimos a las mujeres como participantes secundarias de las festividades, incluso aquellas en donde la principal protagonista era la Luna, asociada a la mujer. Subyace la idea de complementariedad, pero secundando la mujer al hombre en importancia en los contextos ceremoniales. Sin embargo, destaca la unión de lo femenino y lo masculino para lograr la fecundidad de la tierra: en las actividades cotidianas de labranza, los varones aparecen trabajando la tierra con
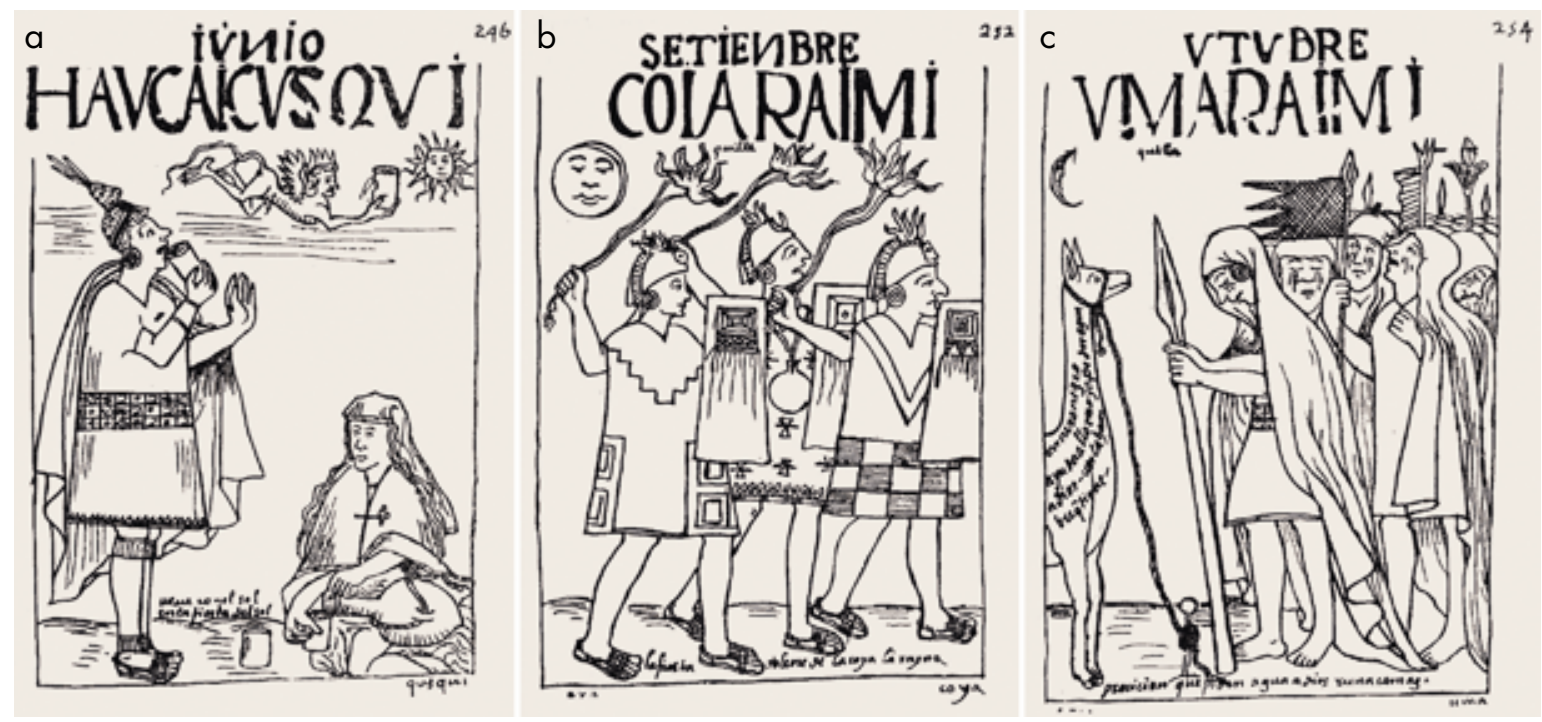

Figura 9. Ceremonias según Guamán Poma de Ayala.

Figure 9. Ceremonies depicted by Guamán Poma de Ayala. 
una chakitablla del lado derecho de las láminas, mientras que las mujeres aparecen de rodillas depositando semillas en la tierra. Si tenemos en cuenta la fiesta de octubre, cuando se realiza la festividad del agua leemos "Carnero negro ayuda a llorar y a pidir agua a dios con la hambre que tiene" (Guamán Poma 1988 [1615]: 229) (fig. 9c). En la lámina vemos un conjunto de personas que lloran pidiendo ayuda divina y en el centro de la escena un orejón quien lleva adelante el oficio ceremonial. En el sector superior derecho, una débil luna que

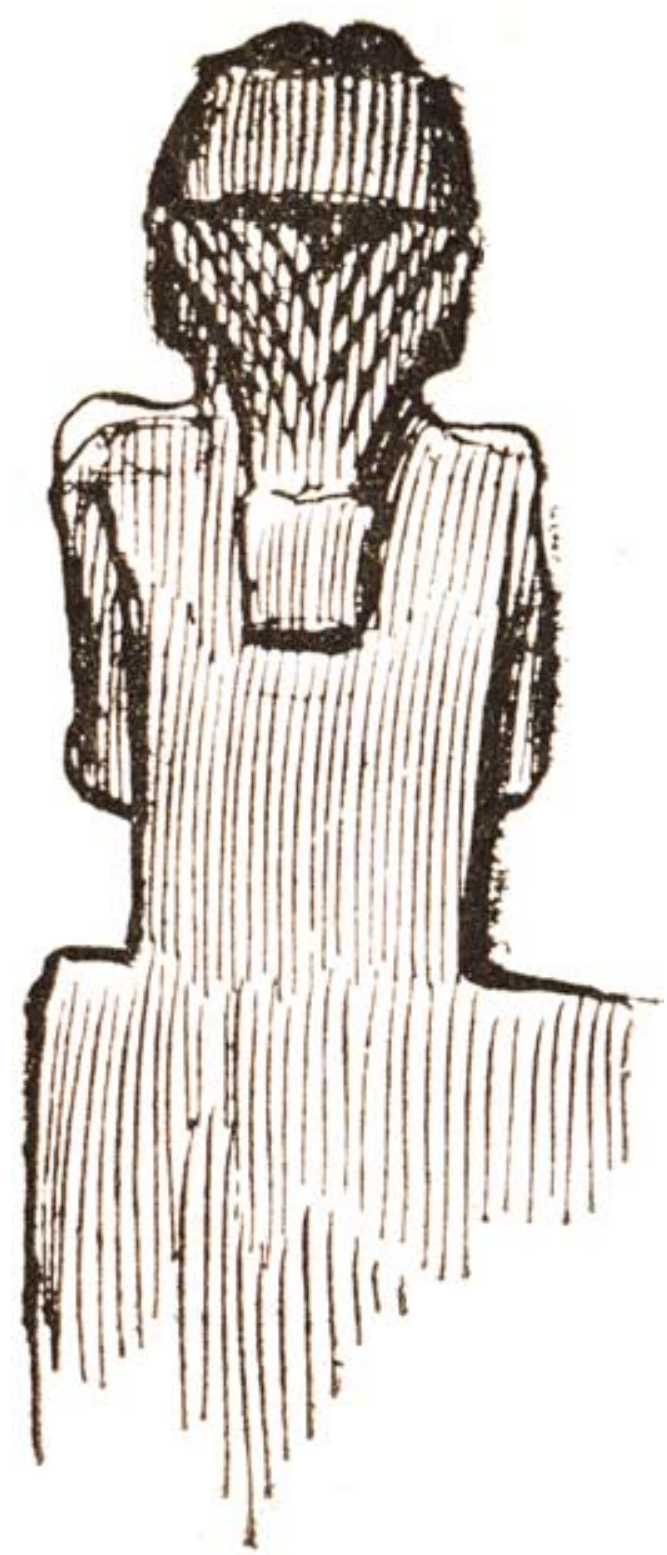

Figura 10. Peinado "tanga" según Ambrosetti (1907: 504, figura 274, alto: $55 \mathrm{~mm}$ ).

Figure 10. "Tanga" hairstyle depicted by Ambrosetti (1907: 504 , figure 274 , height: $55 \mathrm{~mm}$ ). desfallece, ocupa el lugar del Sol, debido a su relación con la fecundidad y los cultivos (González Vargas et al. 2003). La lateralidad de esta escena es explicada de la siguiente manera:

[...] la llama que clama por agua, ocupa el margen derecho de la lámina, ya que su sacrificio la une con el ámbito de lo sagrado reservado a este lado. La luna alumbra la escena debido a que [...] ella está vinculada a la fecundidad de la tierra y por lo tanto, con los sembradíos. Con ella claman también los que se beneficiarán (González Vargas et al. 2003: 183).

A través de esta lámina se sugiere que las mujeres son espectadoras de la ceremonia pero no son sus protagonistas principales. Este rol se detecta en otras situaciones, incluso en diferentes regiones del Tawantinsuyu (por ejemplo, Guamán Poma 1988 [1615]: 238, 240, 242, 266, 268, 289).

Frente a estos casos observamos que esta noción de complementariedad puede estar ocultando una ideología de desigualdad de género. Las fuentes ilustran a las mujeres vinculadas principalmente a las tareas diarias, tales como el hilado, y como ayudantes en contextos rituales al servir y ofrecer chicha, que seguramente ellas mismas producirían. Tal como comenta Guamán Poma de Ayala: "hilar y lleuar agua y lauar y cocinar, que es oficio de muger y donsella que conbiene" (Guamán Poma 1988 [1615]: 205). Sin duda las opiniones son imparciales y resulta sospechoso los parecidos de estas labores con los de las mujeres europeas del siglo xvi. Sin embargo, la conjunción de fuentes y expresiones artísticas sugieren que las mujeres actuarían principalmente en el ámbito doméstico-privado o como ayudantes en contextos ceremoniales. Según Guamán Poma, los peines, junto a los espejos y los topus, son parte del universo femenino diario del aseo personal (Guamán Poma 1988 [1615]). Posiblemente, las mujeres de curacas o de familias de la elite gozaban de privilegios en determinados rituales, pero en segundo plano a las actividades masculinas.

\section{ÁMBITO PRIVADO, ÁMBITO PÚBLICO}

Aunque en escaso número, existen representaciones indudablemente femeninas en objetos vinculados al ritual. Frente a estas, proponemos como hipótesis que se trata de materiales pertenecientes y accesibles a un grupo reducido de mujeres, tales como las hechiceras o las esposas de curacas de las que hablan las fuentes antes consideradas.

Algunas tabletas para inhalar del área de San Pedro de Atacama (norte de Chile), asignadas a un momento post Tiwanaku, muestran representaciones de mujeres (Torres 1984; Aschero 2000), que se caracterizan por 
tener piernas y brazos desplegados, y tres formas romboides ocupan el lugar del pecho y la vagina. Torres (1984) menciona la presencia de una tableta con estas características en Calilegua (provincia de Jujuy). En La Paya, Ambrosetti (1907) identifica, mediante el tipo de peinado, imágenes femeninas menos explícitas sexualmente en tabletas de madera. En una de las tabletas observa tres figuras esculpidas, un hombre ocupando el centro y una mujer a cada lado, siendo

[...] el del centro mayor que los otros, y cubierta la cabeza con una tanga [...] los otros dos, de los lados, se hallan con la cabeza desnuda y el pelo abierto detrás, en dos mitades, por lo que las supongo mujeres" (Ambrosetti 1907: 218).

Asimismo, identifica puntas de bastones en madera, uno de los cuales "muestra un personaje sentado, con el pelo partido por detrás; este peinado es característico de las mujeres" (Ambrosetti 1907, figura 259). La figura 10 muestra el peinado tipo tanga adscrito a los hombres calchaquíes, según Ambrosetti.

Ya hemos hecho mención a dos placas rectangulares elaboradas en metal que poseen representaciones de mujeres. Según A. González (1992: 113) una de ellas corresponde a "una transición de las técnicas y los diseños del Período Medio al Tardío". Se trata de una pieza rectangular (89-90 $\mathrm{mm}$ de alto por $79 \mathrm{~mm}$ de ancho) obtenida por vaciado procedente de Cachi (provincia

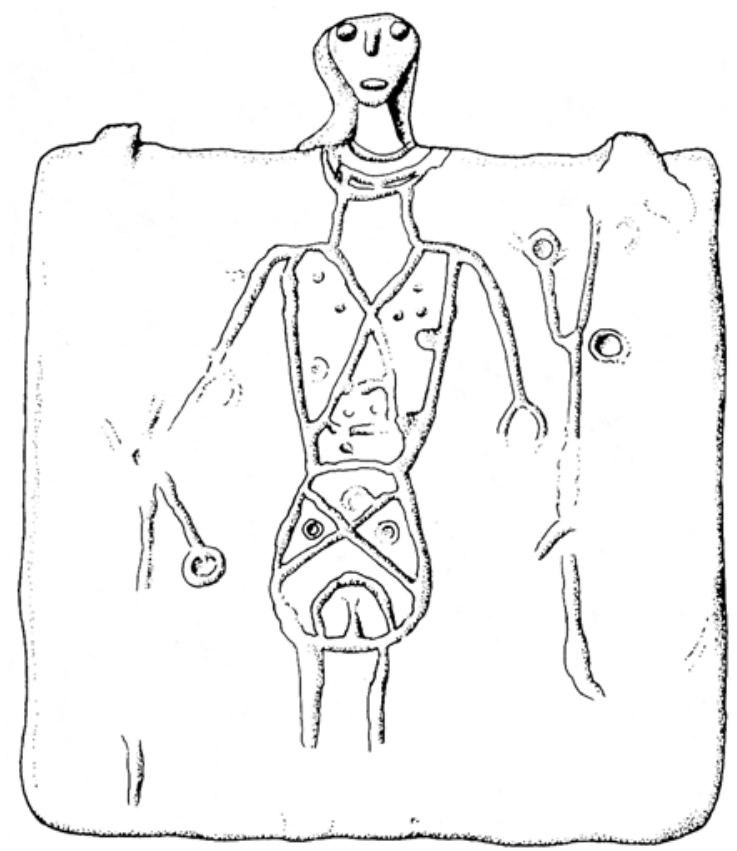

Figura 11. Placa rectangular con representación femenina (tomado de González, A. 1992, lámina 41, alto: 89-90 mm).

Figure 11. Rectangular plate with female representation (from González, A. 1992, plate 41, beight: $89-90 \mathrm{~mm}$ ). de Salta) (González, A. 1992) con una sencilla representación femenina (fig. 11). De pocos milímetros de espesor, posee dos pequeñas protuberancias en la parte superior, donde parece que han estado los agujeros de suspensión. La cabeza, con ojos, boca y nariz, sobresale del borde superior. El diseño del cuello es muy largo y con un collar de tres vueltas. Presenta indicación de genitales femeninos. A. González (1992: 113) detalla que "el tórax es trapezoidal y está dividido por dos líneas diagonales, cuyos campos están formados por puntos. De la cintura abajo también tiene una cuatripartición diagonal, rellena de puntos". Ambrosetti (1904: 270) señala que esta placa habría sido "amuleto propiciatorio con el objeto de obtener buenas cosechas. El órgano genital femenino es un buen indicio que se complementa con los atributos vegetales [en ambas manos], que bien pueden representar plantas de maíz".

La otra placa rectangular $(85 \mathrm{~mm}$ por $95 \mathrm{~mm}$ con 2,5 $\mathrm{mm}$ de espesor) posee el centro vacío y los motivos decorados se ubican en el borde superior de la pieza (fig. 12), en el que se disponen las representaciones de tres rostros antropomorfos. La estructura de diseño se compone de un personaje central masculino flanqueado por dos mujeres. La determinación de género la realizó A. González (1992) a partir del tipo de tocado y/o peinado de las caras. Según este autor, el personaje central posee un tocado similar al que presentan los grandes rostros que se presentan solos en los discos metálicos (p. e., aquel conocido como "disco Vázquez" y descrito previamente), mientras tanto las mujeres poseerían peinados con moños tipo "hopi".

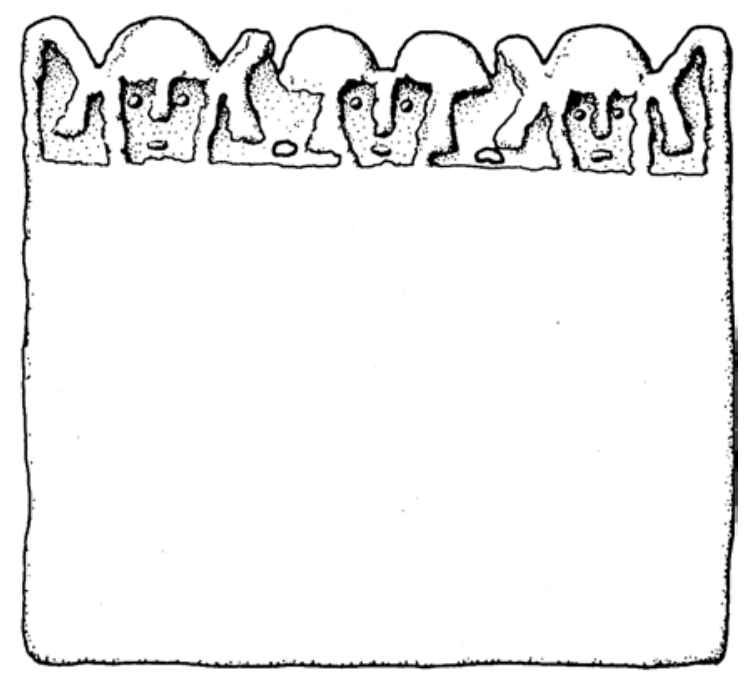

Figura 12. Placa rectangular con figura de tres personajes en el borde superior (tomado de González, A. 1992, lámina 41, alto: $85 \mathrm{~mm}$ ). Figure 12. Rectangular plate with three human heads on the upper edge (from González, A. 1992, plate 41, height: $85 \mathrm{~mm}$ ). 
No conocemos los contextos de uso de estas placas, sin embargo esta última mantiene el mismo patrón de disposición de una figura masculina central y otras dos figuras a sus lados. Por lo general las mismas son imágenes de animales realistas mientras que para el Período Medio se trata de seres fantásticos. Ya hemos mencionado este patrón de diseño para una tabla de rapé de madera encontrada en La Paya donde dos representaciones de mujeres escoltan una masculina (Ambrosetti 1907).

Estas placas, no vinculadas a la esfera del aseo personal, cobran importancia si retomamos algunos aspectos relacionados al culto.

Quiroga (1901: 193) interpretó la placa con la figura de la mujer con vegetales como un cayle con una imagen vinculada a la protección de la agricultura. Al respecto, Lozano (citado en González, A. 1992: 183) comenta que los calchaquíes

[...] adoraban al trueno, al rayo, a quien tenían dedicadas unas casas pequeñas [...] No adoraban solas estas deidades en aquellos sus Tiempos, pues rendían culto también en ellos a otros ídolos, que llamaban Cayles, cuyas imágenes labradas en láminas de cobre traían consigo, [...] las ponían con grandes supersticiones en sus casas, en sus sementeras, y en sus Pueblos, creyendo firmemente que con estos instrumentos vinculaban a aquellos sitios la felicidad, [...] y que era imposible de acercarse por allí la piedra, la langosta, la epidemia, ni otra alguna cosa que les pudiese dañar.

Esta cita nos acerca a los ritos que los grupos locales podían llegar a realizar en diversas situaciones, no sólo aquellas en las que se desplegaban los grandes discos metálicos con figuras que encarnaban violencia, sino a ritos vinculados a la fertilidad en los cuales las mujeres pudieron tener un rol más presente.

Retomando la importancia de la lluvia y su vínculo con la fertilidad podemos interpretar desde la perspectiva de género aquellas referencias presentes en las crónicas acerca del uso de alucinógenos para provocar la lluvia por parte de los chamanes (González, A. 2007 [1977]:107). En una sociedad como la andina, donde la dualidad era un concepto elemental de su cosmovisión, sugerimos como hipótesis que si el conseguir el agua era tarea de ciertos hombres, aquellos con relación a las deidades, algunas mujeres eran las encargadas de servirla en los oficios ceremoniales. Pero esta idea de roles complementarios no implica igualdad de condiciones sociales. Si bien las mujeres andinas de alto estatus habrían participado en la preparación y distribución de chicha en convites políticos o rituales (Gero 2001) no podemos establecer cuál era su significado para sus protagonistas. Como expresa Gero "finalmente, los datos arqueológicos, como las interpretaciones iconográficas, requieren de un marco, y el marco que necesitan pro- viene igualmente de la teoría de género" (Gero 2001: 52; la traducción es nuestra).

A nuestro entender, el análisis de estas expresiones en metal pone de manifiesto a lo femenino como inmediatamente visible y desprotegido. Lo masculino está oculto tras los ropajes y sus actividades guerreras o sociales. Proponemos como hipótesis que para el momento estudiado existía el reconocimiento de un poder creador fecundo en la mujer pero que sólo podía ser puesto al servicio de la sociedad por los hombres, a partir de la conjunción de violencia y consentimiento (Godelier 1989). La placa rectangular donde dos mujeres aparecen secundando al personaje masculino principal fortalece la idea de que actuaban respecto a los lazos de los hombres con entidades sobrenaturales. Lo femenino, por lo tanto, se expresa principalmente en el ámbito de la cotidianeidad, mientras que en la esfera ritual su capacidad de fertilidad se vincula a unión de lo femenino y lo masculino.

\section{COMENTARIOS FINALES}

El estudio de los diseños antropomorfos de los objetos ceremoniales metálicos tomados en su conjunto permite ver que, si bien a primera vista las caras santamarianas pueden ser interpretadas como una representación humana asexuada, su contextualización con el resto del universo de las figuras, así como dentro de sus esferas de uso, conduce a considerar que se trata de imágenes masculinas "en diálogo". Incluso cuando se presentan solas, pertenecen a una esfera pública de uso, mientras que las femeninas operan en una más privada. En este sentido, y a pesar del caso de las dos placas (figs. 11 y 12), las mujeres están pobremente presentes en los metales de uso ceremonial en las sociedades tardías del NOA lo cual no deja de estar en sintonía con la tradición metalúrgica en el área. Las pequeñas dimensiones y el poco peso de las placas dan cuenta de una esfera ritual diversa a la de los grandes discos, campanas y hachas vinculadas, a nuestro entender, con el despliegue de estatus social y representaciones religiosas a gran escala.

Aparte de estas dos placas, hemos presentado previamente objetos metálicos asociados a la esfera del aseo personal. No debemos olvidar que la metalurgia fue sin duda la tecnología más compleja implementada por las poblaciones prehispánicas del NOA. Si, como hemos dicho, constituyó una tecnología de poder, cabe preguntarse quienes podían poseerlos. Al respecto la información que aporta el Inca Garcilaso vinculada a los espejos (posiblemente también asociados al aseo femenino) es de interés: 
Los espejos en que se miraban las mujeres de la sangre real eran de plata muy bruñida, las comunes en azófar, porque no podían usar de la plata [...] Los hombres nunca se miraban al espejo, que lo tenían por infamia, por ser cosa mujeril (Garcilaso de la Vega 2005 [1617]: 137). ${ }^{7}$

Dada la dificultad de elaboración y la inversión de energía social involucrada en la elaboración de los peines, no todas las mujeres accederían por igual a los mismos. Proponemos de este modo que en la distribución sexuada de los bienes metálicos se reflejarían asimismo las diferencias sociales. Estas pequeñas piezas metálicas dedicadas al cuidado personal femenino, y que sólo se usarían en el ámbito privado, poseían cualidades que las alejaban de los peines de madera, no sólo en lo que respecta a las dificultades técnicas requeridas para lograr su elaboración, sino también en sus propiedades físicas únicas: la dureza, la durabilidad, el color, el brillo, el reflejo de la luz y el sonido.

En este sentido, nos preguntamos si dada su capacidad de reflejar la luz, y ante la cita previamente comentada del Inca Garcilaso (2005 [1617]), el cuerpo del peine, y su parte lisa sin decoración, no pudieron funcionar como espejos no sólo en sentido metafórico, agregándole una función adicional vinculada al mundo femenino, pero en estrecha vinculación con el mundo mítico, conjugando al mismo tiempo cotidianeidad y sacralidad.

De este modo podemos ver una correlación entre estos pequeños objetos de uso personal y privado y otros bienes metálicos, como las placas metálicas del NOA entre cuyas funciones destaca la de proyectar luz (González, A. 1992).

Los momentos prehispánicos tardíos se caracterizaron por profundos cambios en la organización de las sociedades. Hacia finales del primer milenio en el área valliserrana del NOA la agricultura de regadío y la explotación ganadera fueron expandidas e intensificadas, lo que condujo a un aumento demográfico reflejado en el crecimiento de extensos poblados aglomerados hacia mediados del siglo XIII o incluso antes (entre otros, Tarragó 2000). La mayor complejidad de las actividades político-ceremoniales promovió la elaboración de bienes de prestigio, entre los cuales los bronces estañíferos ocuparon un lugar destacado y para cuya elaboración operaron auténticos talleres especializados (Tarragó \& González 1996). La alta representatividad de guerreros o personajes de alto estatus en bienes destinados a ser empleados dentro de la esfera político ceremonial puede explicarse en este contexto de conflicto social endémico. Las imágenes femeninas en metal no están ajenas a este proceso a gran escala ya que su exhibición remitía a las esferas sagradas y constituían vehículos de ostentación de estatus diferenciales incluso en actividades privadas no religiosas: el discurso del poder empleaba las características materiales particulares del metal para marcar diferencias entre grupos e identidades sociales (Núñez L. 1999). Esto se debe a que tanto los minerales metálicos como sus procesos de transformación guardaban estrechos lazos con profundas concepciones andinas sobre las relaciones entre los seres humanos, la naturaleza y las potencias que gobernaban el universo (González, L. 2006).

El análisis de las representaciones visuales analizadas, sumadas a otros elementos de la cultura material y fuentes históricas, permiten construir un cuadro social en el cual si bien mujeres y varones tenían mundos diferenciados de género, eran interdependientes y complementarios. Las mujeres representadas nos hablan de un mundo del aseo personal, de las actividades cotidianas, del cuidado de los niños, mientras que otras fuentes de información nos revelan su papel en actividades rituales siendo ayudantes de los hombres: eran principalmente ellos los encargados de intermediar con las deidades. Así, podemos hablar de complementariedad de género, pero no necesariamente igualdad en todos los terrenos.

Profundizando el análisis, observamos que hombres y mujeres tampoco representan entidades abstractas, sino que las imágenes reflejan otras categorías sociales, identidades y roles, lo cual se traduce en rangos sociales y accesos diferenciales a recursos y prácticas. Es decir, los hombres representados no son los hombres comunes, más difíciles de identificar en estos momentos tardíos. En este sentido vemos que no es fácil distinguir género y no siempre podemos identificarlo.

Este trabajo no agota las posibilidades. Quedan muchas preguntas pendientes, vinculadas a relaciones de género. ¿Estamos frente a representaciones de jóvenes mujeres? ¿Cómo reconocer los hombres comunes? ¿A quiénes representan las mujeres y los hombres sin tocados? ¿Cómo y por qué fueron cambiando las representaciones de las mujeres en el NOA a lo largo del tiempo? ¿A qué se debe su baja representatividad en determinados momentos? ¿Qué pasa con las imágenes de especies combinadas (jaguar/serpiente-hombre)? ¿Cómo aproximarnos a las figuras de mujeres con niños en brazos? (Ambrosetti 1907; Debenedetti 1908) (fig. 13).

El análisis de las representaciones humanas en bienes metálicos desde una perspectiva de género constituye una vía adicional de indagación de las materialidades de los objetos y sus significados sociales. A través de los materiales, del modo de procesarlos y de las prescripciones para su uso, se expresaron los fundamentos de la cosmovisión andina y los principios que regulaban el devenir del mundo, además de materializarse la ideología que gobernaba la vida cotidiana (González, L. 2002: 23), 


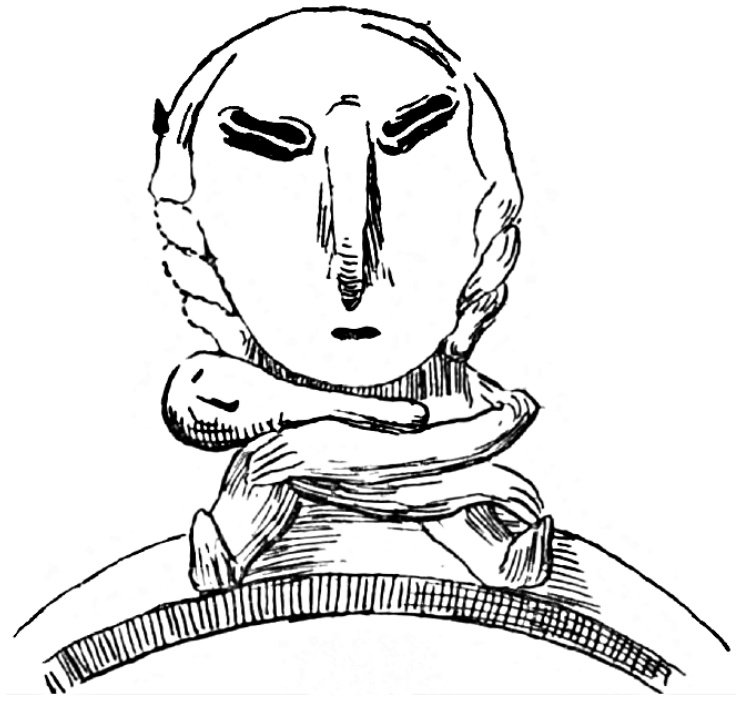

Figura 13. Imagen femenina con niño (tomado de Debenedetti 1908: 33, figura 21, alto: $70 \mathrm{~mm}$ ).

Figure 13. Image of female with child (from Debenedetti 1908: 33, figure 21, height: $70 \mathrm{~mm}$ ).

en las que las relaciones de género eran basales de la dinámica social (Reid \& MacLean 1995). La imagen -y las representaciones del cuerpo subyacentes- actuaban como mecanismo de concentración y ejercicio del poder simbólico, principal medio para controlar la organización de la fuerza de trabajo en las formaciones sociales poco desarrolladas (Bourdieu 1997). Las representaciones del cuerpo y sus atavíos o desnudeces nos hablan, como otras evidencias materiales, de la estructura jerárquica de la sociedad no sólo entre elite y gente común, sino entre géneros.

En este trabajo nos propusimos mostrar que el estudio de género puede ser incorporado en forma habitual en los análisis iconográficos a partir de cuestionarse acerca de los roles de hombres y mujeres. No se trata de una propuesta de revalorizar únicamente a la mujer, sino de buscar qué lugar -cómo y por qué- ocupó en las sociedades pasadas. Para eso debemos necesariamente desnaturalizar nuestro punto inicial de partida, que es nuestra propia experiencia de géneros. Esta postura dista de un simple activismo feminista, en cambio, a través de este caso buscamos ejemplificar cómo el estudio de incluso pocos objetos puede llevar a discusiones más amplias. Sin embargo hay que tener en cuenta que estas reflexiones no necesariamente pueden trasladarse a todos los objetos ni a todas las épocas dentro de la secuencia histórica del NOA. Por el contrario, cada uno de ellos necesita un abordaje pormenorizado. Es importante destacar que la representación no necesariamente refleja la realidad, sino el deseo de un orden social que no siempre se ajusta a esa realidad. De este modo, si bien las omisiones y las alusiones de las figuras femeninas aportan información sobre las relaciones de género deben ser cotejadas con otras líneas de información. El análisis de los tipos de alimentación según sexo (Hastorf 1991), de distribución de objetos en los sepulcros y en diversos contextos rituales y domésticos permite ampliar y enriquecer los estudios de género al avanzar en el grado de estas diferencias, al tiempo que nos explican las omisiones intencionales en las imágenes.

RECONOCIMIENTOS A la Lic. Georgina Gluzman quien a través de charlas cotidianas me permitió acercar a los estudios de género. A los evaluadores por sus comentarios a la primera versión de este trabajo.

\section{NOTAS}

${ }^{1}$ El estilo santamariano, característico del Período Tardío en los valles calchaquíes, posee en la cerámica el mayor corpus de los motivos iconográficos que lo definen.

${ }^{2}$ Diseño de guerreros típicos de la Fase IV de las urnas santamarianas aparecen en aríbalos inkaicos (Nastri 2005), indicándonos también su expresión cultural tardía.

${ }^{3}$ Este alfiler de $260 \mathrm{~mm}$ de largo se caracteriza por presentar una modalidad gráfica que lo aleja del patrón estilístico santamariano. Por lo tanto no ha sido contemplado en la discusión de este trabajo. Baste mencionar que procede de Casabindo (Puna jujeña) y sobre la paleta chata ovalada que forma la cabeza de la pieza se encuentra representada la imagen de un personaje con larga túnica asociada a una llama y un uso de hilar (Ambrosetti 1904). Asimismo, dado que la llegada del imperio Inka al NOA implicó la influencia de otras formas de representación humana, no nos detendremos profundamente en el análisis de este objeto.

${ }^{4}$ Colección González (1912), número 6829. Expresamos nuestro reconocimiento al Director del Museo de La Plata, Dr. Rodolfo Raffino y al personal del depósito de Arqueología, Gabriel Alarcón y Jorge Kraydeberg, por facilitarnos el estudio de esta pieza.

${ }^{5}$ Nos servimos del concepto empleado por Scattolin (2003) para hacer referencia a aquellos objetos en cuya forma está involucrada la figuración del personaje representado.

${ }^{6}$ Esta tabla busca mostrar en términos cuantitativos los valores relativos expresados en el cuerpo del texto acerca de las diversas representaciones de género de acuerdo a los soportes y los momentos de desarrollo histórico en el NOA. Los datos volcados son preliminares y suman en total 110 piezas; la información se generó a partir de la lectura de los trabajos empleados como antecedentes en este artículo. Existió la dificultad de determinar género en algunos casos y de evaluar la totalidad de los datos de la tabla. Esto respondió a la calidad de la imagen o a la perspectiva de la fotografía que no permitía relevar todos los aspectos. Asimismo no es una recolección exhaustiva porque cada uno de estos trabajos de consulta proponía diferentes objetivos, por lo cual existió un sesgo generado a partir de la selección de las fotos por los autores. Esta tabla refleja el estado del avance en el estudio encarado por nosotros acerca de género en otros soportes aparte del metálico. Como hemos dicho en la introducción del artículo, éste tiene como objetivo principal el presentar piezas metálicas que poseen figuras con atributos femeninos y su relación con otras piezas de metal. Sin embargo el incluir la tabla facilita reconocer variaciones con otros soportes. Por lo tanto, la tabla no genera datos concluyentes, sino tendencias en las piezas estudiadas.

La suma de las dos primeras filas horizontales ("rasgos sexuales explícitos" y "sin rasgos sexuales explícitos") remite a la cantidad total 
de piezas relevadas (110) para los tres períodos considerados. Las filas restantes muestran valores de presencia de ciertos rasgos en esas imágenes antropomorfas. Por ejemplo aquel que remite a la ausencia de todo rasgo de vestimenta (desnudez) está representado para las cerámicas con representaciones femeninas del Período Temprano 10 veces, mientras que en cerámicas del mismo momento pero con representación masculina ese rasgo no se presenta (ya que no hemos interpretado la presencia de tatuajes corporales como desnudez). A partir de la combinación de estos atributos seleccionados se determinó a qué género pertenecía cada figura. Por último es importante mencionar que se han excluido de la tabla las urnas santamarianas como totalidad de representación de género y sólo se han analizado sus diseños pintados o en pastillaje.

${ }^{7}$ Azófar es la aleación de cobre y cinc, de color amarillo pálido y susceptible de gran brillo y pulimento. Garcilaso de la Vega (2005 [1617]) emplea este término para definir las aleaciones de cobre con estaño, típica de los momentos inkaicos.

\section{REFERENCIAS}

AlBerTI, B., 2007. Destabilizing Meaning in Anthropomorphic Vessels from Northwest Argentina. Journal of Iberian Archaeology 9/10: 209-230, Porto

AlBerTI, B. \& Y. MARSHALL, 2009. Animating Archaeology: Local Theories and Conceptually Open-ended Methodologies. Cambridge Archaeological Journal 19: 344-356, Cambridge.

Ambrosetti, J. B., 1895. Las grutas pintadas y los petroglifos de Salta. Boletín del Instituto Geográfico Argentino 16: 26-31, Buenos Aires

— 1897. La antigua ciudad de Quilmes (Valle Calchaquí). Boletín del Instituto Geográfico Argentino 18: 33-70, Buenos Aires.

— 1899. Notas de arqueología Calchaquí. Buenos Aires: Imprenta La Buenos Aires.

— 1904. El bronce en la región calchaquí. Anales del Museo Nacional de Buenos Aires 11: 163-312, Buenos Aires.

— 1907. Exploraciones arqueológicas en la ciudad prehistórica de La Paya. Revista de la Universidad de Buenos Aires 8, Buenos Aires.

AmiGó, M., 2000. El desafío de Calchaquí. Un puñado de jesuitas "entre un mar de indios". La intervención de la Compañía de Jesús en el valle Calchaquí (siglos XVI y XVII). Tesis de Licenciatura en Ciencias Antropológicas, Universidad de Buenos Aires.

— 2001. Carta Anua de la Provincia del Paraguay, años 16531654. Transcripción de segmentos. Memoria Americana 10 177-236, Buenos Aires

Arriaza, B.; M. Allison, V. Standen, G. Focacci \& J. Chacama, 1986. Peinados precolombinos en momias de Arica. Chungara 16-17: 353-375.

Aschero, C., 2000. Figuras humanas, camélidos y espacio en la interacción circumpuneña. En Arte en las rocas: arte rupestre, menhires y piedras de colores en Argentina, M. Podestá \& M. de Hoyos, Eds., pp. 15-44. Buenos Aires: Sociedad Argentina de Antropología.

BOuRDieu, P., 1997. Espacio social y espacio simbólico. Introducción a una lectura japonesa de La Distinción. En Capital cultural, escuela y espacio social, I. Jiménez, Ed., pp. 23-40. Buenos Aires: Siglo XXI Editores.

BRUMFIEL, E., 2001. Asking about Aztec gender: The historical and archaeological evidence. En Recovering Gender in Prehispanic Mesoamerica, C. F. Klein, Ed., pp. 57-84. Washington: Dumbarton Oaks.

Bunster, C., 2001. Las autoridades indígenas y los símbolos de prestigio. Andes 12: 83-122, Salta.

CAvicCHIOLI, M., 2006. Arqueología de género del mundo grecorromano. En Género y etnicidad en la arqueología sudamericana, V Williams \& B. Alberti, Comps., pp. 97-101. Olavarría: UniCEN.

Cigliano, E., 1958. Arqueología de la zona de Famabalasto. Departamento de Santa María (Provincia de Catamarca).
Revista del Museo de La Plata V, Antropología V (24): 29-122, La Plata.

Conkey, M., 2003. Has Feminism Changed Archaeology? Journal of Women in Culture and Society 28 (3): 867-880, Chicago.

Debenedetti, S., 1908. Excursión arqueológica a las ruinas de Kipón (valle Calchaquí, provincia de Salta). Publicaciones de la Sección Antropológica 4: 3-55, Buenos Aires.

Del Techo, N., 1673. Historia de la provincia del Paraguay de la Compañía de Jesús [online] <http://www.bvp.org.py/biblio_htm/ techo2/te2_libro5.htm> [Citado 13-01-10].

GaLlardo, F., 1994. La sustancia privilegiada: turbantes, poder y simbolismo en el Formativo del norte de Chile. En Identidad y prestigio en Los Andes. Gorros, turbantes y diademas, J. Berenguer, Ed., pp. 11-25. Santiago: Museo Chileno de Arte Precolombino.

Garcilaso de la VeGa, I., 2005 [1617]. Comentarios reales de los Incas. Tomo I. México, D. F.: Fondo de Cultura Económica.

Gero, J., 2001. Field Knots and Ceramic Beaus: Interpreting Gender in the Peruvian Early Intermediate Period. En Recovering Gender in Prehispanic Mesoamerica, C. F. Klein, Ed., pp. 15-55. Washington: Dumbarton Oaks.

Godelier, M., 1989. Lo ideal y lo material. Pensamiento, economías $y$ sociedades. Madrid: Taurus.

González, A., 1964. La Cultura de La Aguada del N. O. Argentino. Revista del Instituto de Antropología 2-3: 205-253, Córdoba.

— 1977. Arte precolombino de la Argentina. Buenos Aires: Filmediciones Valero.

— 1983. Nota sobre religión y culto en el noroeste argentino prehispánico. Baessler Archiv. Neue Folge Band XXXI: 219282, Berlín.

— 1992. Las placas metálicas de los Andes del sur. Mainz am Rhein: Verlag Philipp von Zabern.

2007 [1977]. Arte, estructura y arqueología. Buenos Aires: La Marca.

GonZÁlez, L., 2002. A sangre y fuego. Nuevos datos sobre la metalurgia Aguada. Estudios Atacameños 24: 21-37.

— 2006. El poder de los metales. En Tesoros precolombinos del Noroeste argentino, M. Goretti Ed., pp. 93-98. Buenos Aires: Ediciones Fundación CEPPA.

— 2007. Tradición tecnológica y tradición expresiva en la metalurgia prehispánica del Noroeste argentino. Boletín del Museo Chileno de Arte Precolombino 12 (2): 33-48, Santiago.

— 2008. La rebelión de los bronces. Estudios sobre metalurgia prehispánica en el noroeste argentino. En Mina y metalurgia en los Andes del Sur desde la época prebispánica hasta el siglo XVII, P. Cruz \& J. J. Vacher Eds., pp. 57-89. Sucre: Institut de Recherche pour le Développement/Instituto Francés de Estudios Andinos.

González Vargas, C.; H. Rosati \& F. SÁnchez, 2001. Sinopsis del estudio de la iconografía de la Nueva Coronica y Buen Gobierno escrita por Felipe Guaman Poma de Ayala. Historia 34: 67-89, Santiago.

2003. Guaman Poma: testigo del mundo andino. Santiago: Lom.

GoretTi, M. (Ed.), 2006. Tesoros Precolombinos del Noroeste Argentino. Buenos Aires: Ediciones Fundación CEPPA.

Guamán Poma de Ayala, F., 1988 [1615]. El primer nueva corónica $y$ buen gobierno, J. V. Murra \& R. Adorno. México, D. F.: Siglo XXI Editores.

Hastorf, C., 1991. Gender, Space, and Food in Prehistory. En Engendering Archaeology: Women and Prehistory, J. Gero \& M. Conkey, Eds., pp. 132-163. Oxford: Blackwell.

IsBell, B., 1997. De inmaduro a duro: lo simbólico femenino y los esquemas andinos de género. En Más allá del silencio. Las fronteras de género en los Andes, D. Arnold, Comp., pp. 253300. La Paz: ILCA-CIASE.

Lehmann-Nitsche, R., 1904. Catálogo de las antigüedades de la Provincia de Jujuy. Revista del Museo de La Plata XI: 75-120, La Plata. 
Muscio, H., 2006. Aproximación evolutiva a la complejidad y al orden social temprano a través del estudio de representaciones rupestres de la quebrada de Matancillas (Puna argentina). Estudios Atacameños 31: 9-30.

NASTRI, J., 2005. El simbolismo en la cerámica de las sociedades tardías de los valles Calchaquíes (siglos XI a XVI). Tesis Doctoral, Facultad de Filosofía y Letras, Universidad de Buenos Aires.

NúÑEZ, L., 1999. Valoración minero-metalúrgica circumpuneña: Menas y mineros para el Inka rey. Estudios Atacameños 18: $177-221$.

Outes, F. \& C. Bruch, 1911. Los aborígenes argentinos. Buenos Aires: Estrada.

Quiroga, A., 1898. El simbolismo de la cruz y el falo en Calchaquí. Boletín del Instituto Geográfico Argentino 19: 305-343, Buenos Aires.

1901. La cruz en América. Buenos Aires: Imprenta La Buenos Aires.

— 1992 [1897]. Calchaquí. Edición conjunta con Folklore Calchaquí [1929], pp. 321-475 y Petrografias y pictografias de Calchaquí [1931], pp. 227-319. Buenos Aires: TEA Ediciones.

ReID, A. \& R. Maclean, 1995. Symbolism and the social context of iron production in Karagwe. World Archaeology 27 (1): 144-161, London
Ruiz Martínez, A., 2008. Pensar una metodología feminista desde la arqueología: cuando el cuerpo de la mujer toca el cuerpo de la nación. En Feminismos en la antropología: nuevas propuestas críticas, L. Suárez Navaz \& E. Martín Díaz, Coords., pp. 141-155. San Sebastián: Ankulegi Antropología Elkartea.

Scattolin, C., 2006. La mujer que carga el cántaro. En Género y etnicidad en la arqueología sudamericana, V. Williams \& B. Alberti Comps., pp. 43-71. Olavarría: UniCEN.

TArragó, M., 2000. Chacras y pukara. Desarrollos sociales tardíos. En Nueva Historia Argentina Los pueblos originarios y la conquista de América, Tomo I, M. Tarragó, Ed., pp. 257-300. Buenos Aires: Editorial Sudamericana.

TARragó, M. \& L. GonZÁlez, 1996. Producción especializada y diferenciación social en el sur del valle de Yocavil. Anales de Arqueología y Etnología 50/51: 85-108, Mendoza.

Torres, M., 1984. Iconografía de las tabletas para inhalar sustancias psicoactivas de la zona de San Pedro de Atacama, norte de Chile. Estudios Atacameños 7: 135-147.

VELANDIA, C., 2005. Iconografía funeraria en la cultura Santa María, Argentina. Ibagué: Universidad de Tolima.

WeBER, R., 1981. An analysis of Santa Maria urn painting and its cultural implications. Fieldiana Anthropology 2: 1-32, Chicago. 